\title{
The Representation of Women Sensuality in Fiesta Condoms Ads "Safety Airlines" Version on Television
}

\author{
Lisa Fitriana \\ Magister of Communication Science \\ Diponegoro University \\ Semarang, Indonesia \\ lisafitriana.lf@gmail.com
}

\author{
Urip Mulyadi \\ Sultan Agung Islamic University \\ Semarang, Indonesia
}

\begin{abstract}
Advertising in Indonesia many are wearing system sign with figure women who tend to sensuality. Phenomena aesthetics in advertisement put forward exploitation pull power body and sensuality for strengthen sell power from a product as advertisement Condom Fiesta version of Safety Airlines. Advertising manipulation the obscure relation social, class, and gender with identification formed from consumption not productions. Then, deep advertisement Condoms Fiesta Safety Airlines version that specially for man but is displayed with women group who accentuate their sexy body. This research uses Ronald Barthes semiotic analysis which has purpose to represent the meaning of advertisement. The correlation with Condoms Fiesta Safety Airlines version advertisement is many symbols and sign appear in that advertisement. For the meaning itself, researcher using two step signification of Barthes which seen from appear sign (manifest content) and hidden sign (latent content). Researcher also uses sensuality as focus to represent Condoms Fiesta Safety Airlines version advertisement in this research. This research shows the scene clothing sexy, motion scene erotic and there is an expression scene happiness (satisfaction). Message in this advertisement use sensuality women as pull power from body language for consumers interesting. This research too impact for flight attendant women who will looked at as object sex and always wear clothing sexy.
\end{abstract}

Keywords—advertising; gender; sensuality

\section{INTRODUCTION}

Business competition in this globalization era is getting more dynamic. Companies compete in marketing their products and use various interesting ways for their products to be remembered and consumed by public using promotions. One of the effective promotions to introduce and embed the product in consumers' mind is through advertising. Many Ads in Indonesia are still using woman figure as a sensual attraction as of woman is often used as sex object. Based on gender ideology perspective in general, woman in advertisement representation in the mass media and advertisement is put as stereotypical exploitation of woman sexual attraction and woman's body exploitation in advertisement.

Fiesta condom is produced by DKT International. In advertising its products, it has some similar characteristics as other products. They are giving "safety" movement and providing an overview of a woman who is closely related to sex. Condoms are also devoted to men used but in ads, it is using a group of women figures. The interesting point is that it is more meaningful and closer to sexual association towards the audience, which is depicted by a group of young, beautiful, sexy women wearing very tight and minimal clothing which highlight the curves of her body especially around the chest and thighs.

The woman in the ads shows safety in the plane but there are additional movements that show the body's elegance and feel the vital part. That is what makes women often become a disadvantaged object. As happened to the Fiesta condom ads, it shows that woman also used as a sex object commodity. The choice ads by using flight attendant can also bring affects towards flight attendant themselves. Because the flight attendant will be labeled as a sexy woman due to wearing the open dress, given the condom is something sensitive and sexy. The packaging of the flight attendant shows a vulgar impression or aimed to engage in immoral activities resulting in stigmatization that condom is a product aimed for immoral action. Moreover, the ads show happiness expression of men done by jigging.

Based on the above description, it can be said that the representation of the ad is the implication of the ads representation consequences in the first group, namely the ads that has the meaning of body exploitation and the attraction of woman sexuality. It means woman tend to be socialized stereotype, that the value is only found in sexual attraction with the indication lies in the beauty, the flawlessness, the freshness, and the body's flesh, then unconsciously the woman is pushed and even 'forced' to fulfill the demands if she wants to get an award from a society that dominated by patriarchal culture system [1].

The researcher is interested in the Fiesta condoms ads "Safety Airlines Version" because the messages are delivered creatively. In addition, she also interested in the existence of woman sensuality in the ads as well as the stereotype in the society that sexiness and beauty is the main principal of a woman to attract men attention. This study aims to know the 
representation of sensuality in media and for female viewers to be more critical viewing woman sensuality in TV commercial ads. Visual approach in this research is done through semiotics by Roland Barthes, how the signs and everything related to ads, how it works, its relation to other signs, its delivery and its acceptance to those who use. So, researcher tries to analyze and interpret messages, meanings, signs and images displayed in Fiesta condom ads "Safety Airlines Version".

\section{RESEARCH METHOD}

This study is a qualitative research using semiotic analysis. Semiotic Analysis is a method to know the construction of meaning in advertisement, especially in gender pictured in Fiesta condom "Safety Airlines Version" on television with 60 second length. This study is using semiotics theory by Roland Barthes. It tries to explain the sensuality in advertisement and is used to know the relationship between signifier and signified in a sign [2].

Code disclosure in this study is done by finding certain codes implied in the picture and motion. First, it will identify each signifier of the implied image in the appropriate concepts. What is obtained in this first stage (denotation) will build a set of signs. Second, the connotation and myth are expressed as markers pointing to a set of certain ideological fragment marks constructed.

The Fiesta condom ads "Safety Airlines Version" on Television for the 60 second length is the object of this study. It has several perspectives considered to be representative of gender-related symbols in the advertisement, they are: theme, endorse, background, narration, cinematographic techniques, colors, and other supporting signs.

Data analysis in this study done in several steps, (1) Interpreting ads by identifying the symbols, then they are described based on the structure of the denotative and connotative meaning (2) Researching associations or symbols, dissect research objects (3) Data presentation, data compiled as to allow drawing conclusions and taking action.

\section{RESULT AND DISCUSSION}

Fiesta condom is widely well known especially by presenting advertisement related to sensuality. "Safety Airlines Version" is one of Fiesta condom ads. A group of women in showing their sensuality is shown by various scenes, namely (1) sexy clothes, (2) erotic and sensual movements, (3) expression of happiness (satisfaction), and (4) serving men with sensual movements. All the sensuality movements are shown with expression, motion, costume and makeup. A group of women is shown as a flight attendant practicing safety procedure on board. Erotic movements become the main target in the ads. Using condom Fiesta will be save when people are having sexual intercourse. That is what the advertiser wants to convey by showing various movements and introducing the various flavors of the condom Fiesta.

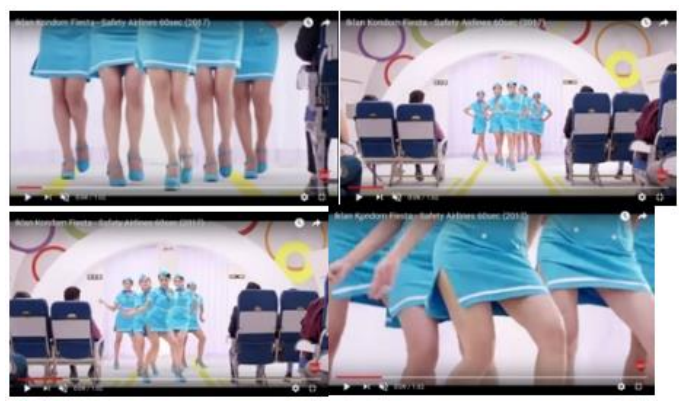

Fig. 1. Scene 1 of the advertisement.

TABLE I. EXPLANATION OF FIGURE 1

\begin{tabular}{|l|l|l|l|}
\hline Scene & Frame & \multicolumn{1}{|c|}{ Denotation } & \multicolumn{1}{c}{ Conotation } \\
\hline 1 & $1-4$ & $\begin{array}{l}\text { Wearing tight } \\
\text { and sexy clothes }\end{array}$ & $\begin{array}{l}\text { Women wearing tight } \\
\text { sexy clothes becom } \\
\text { pleasure object for } \\
\text { Scene 1 and 4 redu } \\
\text { open body parts } \\
\text { attractive sensualit } \\
\text { puts woman as pleas } \\
\text { object. }\end{array}$ \\
\hline
\end{tabular}

Fig. 2. Scene 2 of the advertisement

TABLE II. EXPLANATION OF FIGURE 2

\begin{tabular}{|l|l|l|l|}
\hline Scene & Frame & \multicolumn{1}{|c|}{ Denotation } & \multicolumn{1}{c|}{ Connotation } \\
\hline 2 & $5-8$ & $\begin{array}{l}\text { Gracefully } \\
\text { serving men }\end{array}$ & $\begin{array}{l}\text { Stereotype that woman is } \\
\text { weak, no matter how } \\
\text { educated she is, }\end{array}$ \\
\hline
\end{tabular}

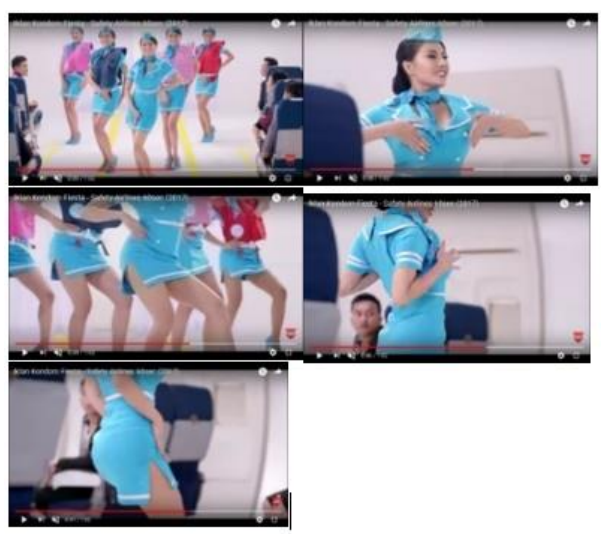

Fig. 3. Scene 3 of the advertisement 
TABLE III. EXPLANATION OF FIGURE 3

\begin{tabular}{|l|l|l|l|}
\hline Scene & Frame & \multicolumn{1}{|c|}{ Denotation } & \multicolumn{1}{c|}{ Connotation } \\
\hline 3 & $6-10$ & $\begin{array}{l}\text { Erotic and } \\
\text { Sensual } \\
\text { Movements }\end{array}$ & $\begin{array}{l}\text { Woman as the sex object. } \\
\text { Woman is an erotic object } \\
\text { enjoyed, used and seen by } \\
\text { man for their pleasure }\end{array}$ \\
\hline
\end{tabular}

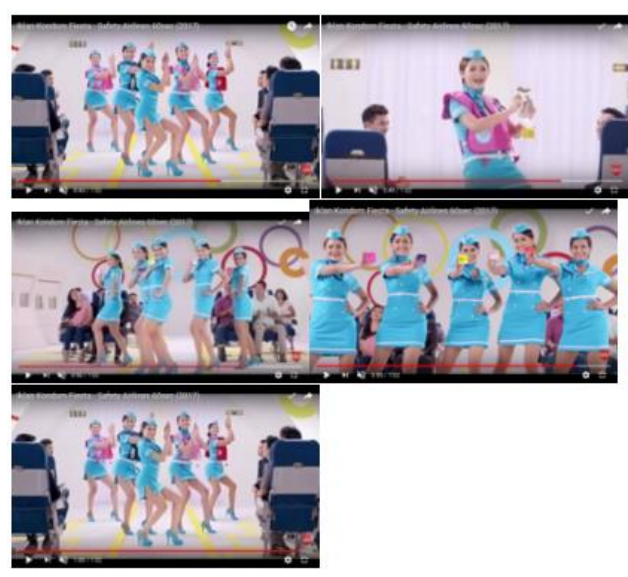

Fig. 4. Scene 4 of the advertisement

TABLE IV. EXPLANATION OF FIGURE 4

\begin{tabular}{|l|l|l|l|}
\hline Scene & Frame & \multicolumn{1}{|c|}{ Denotation } & \multicolumn{1}{c|}{ Connotation } \\
\hline 4 & $11-15$ & $\begin{array}{l}\text { Beauty symbol } \\
\text { in marketing the } \\
\text { product and } \\
\text { happiness } \\
\text { expression }\end{array}$ & $\begin{array}{l}\text { Subordination, man } \\
\text { having higher power than } \\
\text { woman. Man adores } \\
\text { physical beauty }\end{array}$ \\
\hline
\end{tabular}

The scenes in fig. 1,2,3,4 and table 1,2,3,4 shows that woman have become inevitable commodity phenomenon in advertising communication. Woman has been a suggestion of attractiveness towards the actualization of product value. Woman is still used as an advertising model because both man and woman like beautiful, elegant and polite woman. While man likes sexy and sensual woman that used to strengthen the attractiveness of an ad like in Fiesta condoms [3].

Fiesta condoms having various flavors are displayed with beautiful and sexy models in seductive dance. It clearly shows that the image of woman in the ads is only used as sex objects. Gender is built by manipulating the woman body as a sign of certain symbols that are stereotypically attached to woman, such as: minimal clothing, sexy, agility, indulgence, and so forth.

That man is always above woman are pictured and presented in advertisement. Man always gets special privileges while woman is always being the second party and labeled as man slaves. It is shown by men sitting in an airplane pleased by a group of women dancing in front of him, while a group of women are portrayed in performing erotic dance and being male servants.

From the things shown in the Fiesta condom ads "Safety Airlines Version", there are some dominant symbols appear strongly in this ad, woman as sex objects, such as: (a) sexy and minim clothing becomes a sensuality for a woman. In this ad, sexy outfits become a symbol that closely related to sex, generally put woman as objects, can be seen by tight clothes in part or the whole body (sensuality) of woman's appearance. (b) Serving man is a symbol of job for women. (c) Erotic and sensual movements of hip wobbles and widening feet are symbols of utilization of woman's bodies for the sake of business. Highlights the female body on the chest as a symbol that woman are only man slaves exploiting certain parts to attract men attention. (e) The symbol of woman's beauty is a precious thing for woman who can attract man. DKT International raises a theme that beautiful sexy woman with ideal bodies are appropriate for condoms.

The manifest content in condom Fiesta ads describes the atmosphere of a reality taking place in the society. The picture is seen from some scenes in the advertisement. The scene tells about a group of women which shows prominent body parts and serves men on the plane, meaning a social reality that can lead to various perceptions of the society.

Regarding the latent signs in Fiesta condom ads "Safety Airlines Version" describes a perception of the motives, hopes, interests and values of sensuality that exist and develop in the society as found in the scene of sexy clothing, erotic motion, highlight body and serving.

In this study, Fiesta condom wants to create beauty myths for woman and man. Beauty myth is one of social control of woman, especially the image of her physical beauty [4]. The condom Fiesta ad in picturing a group of beautiful and sexy woman is understood as beautiful for both man and woman. This myth has damaged woman and made them obsessed to achieve an ideal image of physical perfection especially for man.

\section{CONCLUSION}

The use of woman as sensuality media advertisement in Fiesta condom ads "Safety Airlines Version" is categorized as capitalism in media. Capitalism makes the female body a material of sign exchange system, in order to develop value by conducting a massive exploration of woman body. This is to explore all the potential especially the power of signs, body language, and body fetishism.

In this ad, there are many scenes showing erotic and sensual movements, sexy clothes and expression of happiness (satisfaction). Messages delivered in advertisements use woman sensuality power to influence consumers. This puts woman as a sex object because it advertises a special condom for man and uses physical beauty to market the product. The ads that use flight attendant also undermine the profession, whereas the flight attendant main duty is to instruct passengers on safety during the flight but in this ad, five beautiful flight attendants demonstrate the importance of condom use in sexual intercourse.

There is a myth used in this advertisement, it is a beauty. Because of culture and belief in the society, woman should be physically beautiful; it makes the woman and man obsessed with beauty. 


\section{ACKNOWLEDGMENTS}

The authors would like to thank UIN Sunan Gunung Djati Bandung which has given opportunity to publish journal writer and the authors are grateful to the parties who have provided input to this research

\section{REFERENCES}

[1] Kasiyan, Manipulasi dan Dehumanisasi Perempuan dalam Iklan. Yogyakarta: Ombak, 2008.

[2] R. Kriyantono, Teknik Praktis Riset Komunikasi. Jakarta: Kencana Prenada Media Group, 2009.

[3] R. Widyatama, Bias Gender Dalam Iklan Televisi. Jakarta: Media Pressindo, 2006.

[4] S. Moriarty, Advertising Edisi Kedelapan. Jakarta : Kencana Prenada Media Group, 2009. 